\title{
Income Diversification through a Crop-Livestock-Forest Integration System in the Midwest Brazilian Region
}

\author{
Clarisse Maia Lana Nicoli ${ }^{1}$, Abílio Rodrigues Pacheco ${ }^{1}$, Cristiane Aparecida Fioravante Reis ${ }^{2}$ and Fábio \\ Venturoli ${ }^{3}$ \\ 1. Embrapa Produtos e Mercado, Rodovia BR-153, Km 4, Caixa Postal 714, Goiânia 74001-970, Goiás, Brazil \\ 2. Embrapa Florestas, Estrada da Ribeira, Km 111, Caixa Postal 319, Colombo 83411-000, Paraná, Brazil \\ 3. Universidade Federal de Goiás, Avenida Esperança s/n, Campus Samambaia, Goiânia 74690-900, Goiás, Brazil
}

\begin{abstract}
Sustainability on farms is a challenge to competitiveness in the globalized market. In this scenario, due to the strong environmental, economic and social appeal, crop-livestock-forest integration systems have been considered as the future of agriculture. Regarding the economic approach, this system is based on the diversification of income generating activities, with revenue entry at different times, rationalization of resource use and reduction of risk of financial losses. Thus, the purpose of this work was to carry out the economic analysis of a crop-livestock-forest integration system, located at Boa Vereda's farm, in the municipality of Cachoeira Dourada in the state of Goiás in the central-west region of Brazil. The system was composed of the following traditional crops of the region: soybean, corn, pasture, beef cattle and eucalyptus. The technical coefficients and the prices used for economic evaluation were obtained from the experimental unit and from the local market when crops were harvested in 2016/2017. The economic indicators used to assess economic viability were the net present value (NPV) and the equivalent annual uniform value (EAUV). The results showed a return greater than the opportunity cost of the land, showing the attractiveness of the crop-livestock-forest integration system. Thus, this system represents an economically viable alternative that, among other benefits, allows the diversification of its sources of income, with a reduction of risk.
\end{abstract}

Key words: Agroforestry system, economic analysis, soybean, corn, beef cattle, eucalyptus.

\section{Introduction}

Integration systems are rational in the use and management of natural resources, which integrate trees, agricultural and/or animal cultures in a scientific, ecologically desirable, feasible operation and socially acceptable manner by the rural producer $[1,2]$. Due to their expressive environmental, economic and social appeal, these systems have been considered the future of agriculture [1, 3].

The benefits of these systems have been highlighted in some opportunities [1-6]. Some of these benefits are: flexibility of use in small, medium and large rural properties and with different profiles; simultaneous production of grains, meat and wood products in the same area; greater efficiency in the use of resources

Corresponding author: Abílio Rodrigues Pacheco, Ph.D., research field: crop-livestock-forest integration system. (water, light, nutrients and capital); intensification of soil nutrient cycling; improvement of the quality and conservation of the productive characteristics of the soil; improvement of animal welfare, due to the greater thermal comfort and carbon sequestration [1-6].

Due to the benefits and appeals for sustainability, there was a significant increase in the areas with these systems in Brazil, which jumped from 1.87 million hectare in 2005 to 11.47 million hectare in 2015 [1, 3, $5,7]$. Currently, these systems correspond to $5.50 \%$ of the Brazilian areas under agricultural use, $83 \%$ of which are planted with crop-livestock integration systems, 7\% with livestock-forest integration systems, $1 \%$ with crop-forest integration systems and $9 \%$ with crop-livestock-forest integration systems [7].

The crop-livestock-forest integration systems, although involving a greater complexity in planning, 
implementation and commitment, have been considered the most promising for the recovery of degraded pasture productivity, diversification of economic activities, promotion of environmental improvements and incorporation of areas already altered for the productive process [8]. In addition, it promotes more significant increases in biodiversity and carbon sequestration $[1,3,5,8]$.

In this scenario, the implementation of a technological reference unit (TRU) with a crop-livestock-forest integration system was initiated by the Empresa Brasileira de Pesquisa Agropecuária (Embrapa) and Rede de Fomento ILPF at Boa Vereda's farm, located in the municipality of Cachoeira Dourada in the state of Goiás [9, 10]. It should be noted that this TRU is one of the oldest located in the central-west region of Brazil and has stood out on a national and international scenario, due to its pioneering in sustainability. Throughout the years, teaching, research, innovation and rural extension activities have been promoted, contributing to a considerable amount of scientific work [11-20].

It is stressed that the sustainability of agricultural properties is a challenge to the competitiveness in the globalized market. With regards to the economic approach, the crop-livestock-forest integration system is based on the diversification of income-generating activities, with revenue entry at different times, rationalization of resource use and reduction of risk of financial losses $[1-3,5]$. In this scenario, the objective of this work was to carry out the economic analysis of a crop-livestock-forest integration system, located at Boa Vereda's farm, in the municipality of Cachoeira Dourada, state of Goiás, central-west region of Brazil.

\section{Materials and Methods}

\subsection{Description of the Area}

The study was conducted at the TRU of the crop-livestock-forest integration system of Embrapa, located at Boa Vereda's farm in the Cachoeira Dourada municipality of the state of Goiás in the central-west region of Brazil. Its geographical coordinates are: latitude $18^{\circ} 29^{\prime} 30^{\prime \prime} \mathrm{S}$, longitude $49^{\circ} 28^{\prime} 30^{\prime \prime} \mathrm{W}$ and at an altitude of $459 \mathrm{~m}$.

The climate is "Aw", according to the classification of Köppen, characteristic of tropical humid climates, with two well defined seasons, dry in winter and humid in summer. Estimates of annual mean maximum temperature, annual mean temperature and average annual minimum temperature are $26.2{ }^{\circ} \mathrm{C}$, $24.9{ }^{\circ} \mathrm{C}$ and $21.9{ }^{\circ} \mathrm{C}$, respectively. The estimated annual rainfall is $1,229 \mathrm{~mm}$. It is observed that in the rainy season it is common to experience short dry periods, ranging from one to three weeks, which can cause considerable losses in agricultural production.

The soil is predominantly red latosol of clay texture. The low natural fertility of the farm soils and the toxicity derived from the high aluminum saturation, limited the root development of the plants, making them more susceptible to the short periods of water shortages in the summer. To solve this problem, the practice of liming has become common.

The area of the crop-livestock-forest integration system is composed of 12.5 ha, corresponding to an old degraded pasture existing in the farm. It is worth noting that the main activity on the farm is extensive cattle ranching.

\subsection{Description of the System Deployment}

In the choice of the components of the system, those of traditional use were chosen in the area covered by the municipality of Cachoeira Dourada and consequently, with the ease of disposal and commercialization of the products. Thus, in year 0 , the agricultural components (soybean-harvest 2009/2010) and forestry (four commercial eucalyptus clones, two of Eucalyptus urophylla and two of $E$. urophylla $\times E$. grandis) were planted. The system was implanted in a spatial arrangement of sets of four eucalyptus rows spaced $3.5 \mathrm{~m}$ apart and $2.5 \mathrm{~m}$ between plants. There was a $36 \mathrm{~m}$ distance between each set of eucalypts, four rows for planting the crop 
and later the pasture $(4(3.5 \mathrm{~m} \times 2.5 \mathrm{~m})+36 \mathrm{~m})$. The density of trees was 344 plants/ha, and this component occupied $27 \%$ of the total area. The agricultural component occupied the remaining $73 \%$ of the area.

Due to the state of soil degradation and compaction, its preparation was carried out by means of two heavy harrowing operations to incorporate the limestone, followed by two operations with a grade leveller, completed shortly before the planting of the soybeans and eucalyptus. Liming and planting fertilization were based on the technical recommendation based on the soil analysis result.

Between the rows of eucalyptus seedlings, planted $36 \mathrm{~m}$ apart, the soybean was planted as the first crop. The next year after planting the soybean, corn was planted simultaneously with fodder (Panicum maximum species) to be used for cattle grazing after the corn was harvested. In this type of consortium, one of the compromising factors of yield and quality of the corn production is competition with the grass in the first $50 \mathrm{~d}$ after planting. In this way, an herbicide was applied to temporarily inhibit the fodder growth and reduce its competitive effect for water on the corn.

After the corn harvest, there was a rapid regrowth of the fodder and the eucalyptus already had a degree of development that allowed the animals to enter, without risk of compromising the forestry component of the animals. The animals of mixed breeds introduced in the system presented average mass of $242 \mathrm{~kg}$. During the year, the feeding of these animals was done through grazing. The amount of supplement per animal varied depending on the weight of the animal $(0.01 \%$ of live weight).

The beef cattle were introduced into the system for the purpose of rearing and fattening them. The commercialization of the animals at the slaughter point and, consequently the replacement with new animals occurred once a year. The animals will remain in the system until the eucalyptus trees are cut at the age of 14 years old, a stage in which this integration system cycle will be completed.
Over the years, maintenance of the system is carried out with pasture maintenance fertilization annually, to maintain support capacity during the grazing cycle of the system. The control of invasive plants has been carried out with chemical control. In the conduction of the system, integrated pest management has also been carried out.

\subsection{Productivity Estimates}

The productivity of the agricultural components (soybean and corn), expressed in $\mathrm{kg} / \mathrm{ha}$, was obtained by quantifying production in the total area divided by the number of hectares. It should be noted again that the agricultural components occupied only $73 \%$ of the area of 1 ha.

The productivity of the beef component, expressed in arrobas/ha/year (each arroba equals $30 \mathrm{~kg}$ of live weight), was obtained by means of the average weight of all the animals slaughtered that have passed through TRU since its inception. For calculation purposes, this value was also extrapolated until the end of the cycle of the integration system. As the pasture will be fertilized, in order to maintain an adequate replacement of nutrients in the soil, it is considered the same stocking rate until the final eucalyptus's cutting and the renewal of the system occur.

The productivity of the forestry component (eucalyptus), expressed in $\mathrm{m}^{3} / \mathrm{ha} /$ year, was obtained by means of a forest census carried out at the age of seven years. For this, the diameters at breast height (DBH) of the 3,536 surviving trees in the integration system were measured. To study the dependence relationship between the DBH and heights of the clones, 34 pairs of DBH were measured in each row, totaling 68 pairs of data per clone. The regressions were considered significant, which made it possible to quantify the dependence relationship between these two traits and to adjust the hypsometric relation. After identifying the hypsometric relationship, an estimate was made for the height of each of the measured trees. With these values, estimates were made for the total 
volume of standing wood and the respective confidence intervals at $5 \%$ probability. The volume of the trees was done considering a form factor equal to 0.55 .

The average wood productivity estimate was used to simulate two wood sales scenarios. Considering a total cut of trees at six years of age, this is the usual age for commercialization of fuelwood in the Cachoeira Dourada region (scenario 1) and another scenario considering a $30 \%$ reduction of the trees at the age of six years fuelwood and final cutting of the remnants $(\operatorname{logs})$, at the age of 14 , for lumber use (scenario 2). In both cases, it was considered the responsibility of the buyer of the log to bear the costs of cutting, shipping and transporting the logs.

\subsection{Economic Analysis: Costs and Revenues}

For economic evaluation of the project, from November 2016 to May 2017, information was collected on technical coefficients and marketing prices of soybean, corn, beef cattle and the prices of fuelwood and sawmill use at local markets. These data were collected in order to delineate the production systems and cultural practices adopted, through interviews with producers and other actors in these segments.

\subsection{Financial Evaluation}

In order to identify production costs, the following financial indicators were used: net present value (NPV) and equivalent annual uniform value (EAUV), according to the methodology proposed by Buarque [21] and Rezende and Oliveira [22]. To analyze the economic viability of the integration system, an interest rate of $6.75 \%$ per annum was considered. It should be noted that this is the average rate practiced in recent years by development agencies of the Federal Government of Brazil.

\section{Results and Discussion}

In the markets for products analyzed: soybean, corn, beef arroba and eucalyptus wood, the prices received were defined by market forces and it is not possible for individual producers to affect prices. Thus, rural producers are considered price takers, making cost control even more relevant as an instrument of profitability [23]. Further details of the average prices practiced in the Cachoeira Dourada market can be observed in Table 1.

For the analysis of the production process, a data matrix of the activities was elaborated, reporting the main operations executed for the production of the agriculture, livestock and forestry components. The amounts of machine hours and the use of labor were broken down in each phase of the productive cycle (Tables 2-4). The cost of working hours of the machines and implements was quantified according to the amount of rent paid in the region of the municipality of Cachoeira Dourada, which represented expenses with fuel, lubricants, repairs, maintenance, housing, depreciation and manpower (the machine operator). Prices of inputs (prices paid) and products (prices received), expressed in Reais (R\$) (Brazilian currency), refer to what was practiced in the 2016/2017 crop harvests in that region.

Table 1 Estimates of commodity prices used in the crop-livestock-forest integration system, planted at at Boa Vereda's farm, in the municipality of Cachoeira Dourada, Goiás, Brazil.

\begin{tabular}{lll}
\hline Commodity & Unit & Price $(\mathrm{R} \$)^{*}$ \\
\hline Soybeans & sack & 72.00 \\
Corn & sack & 21.00 \\
Cattle breeding & sack & 130.00 \\
Fuelwood FOB & $\mathrm{m}^{3}$ & 47.14 \\
Wood for cut lumber FOB & $\mathrm{m}^{3}$ & 180.00 \\
\hline
\end{tabular}

* October 15th, 2017; US\$1.00= R\$3.146.

FOB: free on board. In this type of freight, the buyer assumes all risks and costs with the transportation of the merchandise. 
Table 2 Production costs of 1 ha of soybean and eucalyptus (year 0 ) in the crop-livestock-forest integration system, with a spatial arrangement of $4(3.5 \mathrm{~m} \times 2.5 \mathrm{~m})+36 \mathrm{~m}$, at Boa Vereda's farm, in the municipality of Cachoeira Dourada, Goiás, Brazil.

\begin{tabular}{|c|c|c|c|c|c|c|}
\hline \multirow{2}{*}{ Specification } & \multirow{2}{*}{ Unit } & \multicolumn{2}{|c|}{ Quantity } & \multicolumn{2}{|c|}{ Value $(\mathrm{R} \$)^{*}$} & \multirow{2}{*}{ TOC $(\%)$} \\
\hline & & Area $=100 \%$ & Area $=73 \%$ & Unit & Total & \\
\hline \multicolumn{7}{|l|}{ 1. Soybeans-year 0} \\
\hline \multicolumn{7}{|l|}{ Inputs } \\
\hline $\begin{array}{l}\text { Dolomitic limestone: liming } \\
\text { (put on the farm land) }\end{array}$ & ton & 2.00 & 1.46 & 110.00 & 160.60 & 5.12 \\
\hline NPK fertilizer $(8-30-10+Z n)$ & ton & 0.40 & 0.29 & $1,300.00$ & 379.60 & 12.10 \\
\hline Pre-emergent herbicide & $\mathrm{L}$ & 4.00 & 2.92 & 16.00 & 46.72 & 1.49 \\
\hline Herbicide & $\mathrm{kg}$ & 0.05 & 0.04 & 350.00 & 12.78 & 0.41 \\
\hline Certified seeds & $\mathrm{kg}$ & 60.00 & 43.80 & 5.50 & 240.90 & 7.68 \\
\hline Turpentous inoculant & $\mathrm{kg}$ & 0.40 & 0.29 & 15.00 & 4.38 & 0.14 \\
\hline Seed treatment 1 & $\mathrm{~L}$ & 0.10 & 0.07 & 445.00 & 32.49 & 1.04 \\
\hline Seed treatment 2 & $\mathrm{~kg}$ & 0.13 & 0.09 & 33.00 & 3.13 & 0.10 \\
\hline Post-emergent herbicide 1 & $\mathrm{~L}$ & 4.00 & 2.92 & 16.00 & 46.72 & 1.49 \\
\hline Post-emergent herbicide 2 & $\mathrm{~L}$ & 3.00 & 2.19 & 15.00 & 32.85 & 1.05 \\
\hline Fungicide 1 & $\mathrm{~L}$ & 0.50 & 0.37 & 67.00 & 24.46 & 0.78 \\
\hline Fungicide $2-2 \times$ & $\mathrm{L}$ & 0.80 & 0.58 & 183.00 & 106.87 & 3.41 \\
\hline Fungicide 3 & $\mathrm{~kg}$ & 1.50 & 1.10 & 26.00 & 28.47 & 0.91 \\
\hline Insecticide 1 & $\mathrm{~L}$ & 0.60 & 0.44 & 118.00 & 51.68 & 1.65 \\
\hline Insecticide 2 & $\mathrm{~L}$ & 1.00 & 0.73 & 23.00 & 16.79 & 0.54 \\
\hline Insecticide 3 & $\mathrm{~L}$ & 0.35 & 0.26 & 137.00 & 35.00 & 1.12 \\
\hline Insecticide 4 & $\mathrm{~L}$ & 0.12 & 0.09 & 660.00 & 57.82 & 1.84 \\
\hline Insecticide 5 & $\mathrm{~L}$ & 0.50 & 0.37 & 60.00 & 21.90 & 0.70 \\
\hline Insecticide and acaricide & $\mathrm{kg}$ & 1.00 & 0.73 & 31.00 & 22.63 & 0.72 \\
\hline Subtotal of inputs & & & & & $1,325.78$ & 42.26 \\
\hline \multicolumn{7}{|l|}{ Services } \\
\hline Liming & $\mathrm{h} /$ machine & 0.50 & 0.37 & 55.00 & 20.08 & 0.64 \\
\hline Heavy grading (post-liming) & $\mathrm{h} /$ machine & 1.00 & 0.73 & 90.00 & 65.70 & 2.09 \\
\hline Levelling grader $-1 \times$ & $\mathrm{h} /$ machine & 0.50 & 0.37 & 48.00 & 17.52 & 0.56 \\
\hline Herbicide application $-2 \times$ & ha & 2.00 & 1.46 & 28.60 & 41.76 & 1.33 \\
\hline Planting (sowing + fertilizer application) & ha & 1.00 & 0.73 & 30.00 & 21.90 & 0.70 \\
\hline Application of fungicide + insecticide & ha & 1.00 & 0.73 & 28.60 & 20.88 & 0.67 \\
\hline Application of fungicide + acaricide & ha & 1.00 & 0.73 & 28.60 & 20.88 & 0.67 \\
\hline Application of fungicide $-2 \times$ & ha & 2.00 & 1.46 & 28.60 & 41.76 & 1.33 \\
\hline Harvest & $\mathrm{h} /$ machine & 0.81 & 0.59 & 100 & 59.13 & 1.88 \\
\hline Freight (farm-warehouse) & sack & 2.92 & 42.34 & 0.50 & 21.17 & 0.67 \\
\hline Subtotal of services & & & & & 330.76 & 10.54 \\
\hline TOC for soybeans & & & & & $1,656.54$ & 52.80 \\
\hline \multicolumn{7}{|l|}{ 2. Eucalyptus-year $0($ deployment area $=27 \%)$} \\
\hline \multicolumn{7}{|l|}{ Inputs } \\
\hline $\begin{array}{l}\text { Dolomitic limestone: liming } \\
\text { (put on the farm land) }\end{array}$ & ton & 2.00 & 0.54 & 110.00 & 59.40 & 1.89 \\
\hline NPK fertilizer $(8-30-10+Z n)-150 \mathrm{~g} /$ plant & $\mathrm{kg}$ & - & 52.00 & 1.30 & 67.08 & 2.14 \\
\hline $\begin{array}{l}\text { Fertilizer: micro-nutrient (boric acid) } \\
-10 \text { g/plant }\end{array}$ & $\mathrm{kg}$ & - & 3.00 & 3.20 & 11.01 & 0.35 \\
\hline Seedlings (initial planting) & unit & - & 344.00 & 0.70 & 240.80 & 7.68 \\
\hline
\end{tabular}


(Table 2 continued)

\begin{tabular}{|c|c|c|c|c|c|c|}
\hline \multirow{2}{*}{ Specification } & \multirow{2}{*}{ Unit } & \multicolumn{2}{|c|}{ Quantity } & \multicolumn{2}{|c|}{ Value $(\mathrm{R} \$)^{*}$} & \multirow{2}{*}{ - TOC $(\%)$} \\
\hline & & Area $=100 \%$ & Area $=73 \%$ & Unit & Total & \\
\hline Seedlings (re-planting $=10 \%$ ) & unit & - & 34.00 & 0.70 & 24.08 & 0.77 \\
\hline Formicide & grass & 30.00 & - & 1.00 & 30.00 & 0.96 \\
\hline Pre-emergent herbicide 1 & grass & 15.00 & 4.05 & 1.00 & 4.05 & 0.13 \\
\hline Subtotal of inputs & & & & & 436.42 & 13.92 \\
\hline \multicolumn{7}{|l|}{ Services } \\
\hline Liming & $\mathrm{h} /$ machine & 0.50 & 0.14 & 55.00 & 7.43 & 0.24 \\
\hline $\begin{array}{l}\text { Heavy grading } \\
\text { (before and after liming) }-2 \times\end{array}$ & $\mathrm{h} /$ machine & 2.00 & 0.54 & 90.00 & 48.60 & 1.55 \\
\hline Levelling grader $-2 \times$ & $\mathrm{h} /$ machine & 1.00 & 0.27 & 48.00 & 12.96 & 0.41 \\
\hline Formicide application $-5 \times$ & daily & 1.25 & - & 80.00 & 100.00 & 3.19 \\
\hline Plow with moldboard & $\mathrm{h} /$ machine & 3.00 & 0.81 & 90.00 & 72.90 & 2.32 \\
\hline Planting & daily & - & 0.34 & 80.00 & 27.52 & 0.88 \\
\hline Application of fertilizer (NPK) & daily & - & 0.34 & 80.00 & 27.52 & 0.88 \\
\hline Application of fertilizer (boricacid) & daily & - & 0.17 & 80.00 & 13.76 & 0.44 \\
\hline Pre-emergence herbicidal spraying (manual) & daily & - & 0.17 & 80.00 & 13.33 & 0.43 \\
\hline Subtotal of services & & & & & 324.02 & 10.33 \\
\hline TOC for eucalyptus & & & & & 760.44 & 24.24 \\
\hline \multicolumn{7}{|l|}{ 3. Other costs-year 0} \\
\hline Opportunity cost of land (rent) & sack & 10.00 & - & 72.00 & 720.00 & 22.96 \\
\hline TOC-year 0 & & & & & $3,136.98$ & 100.00 \\
\hline
\end{tabular}

* October 15th, 2017; US\$1.00 = R \$3.146.

TOC: total operational cost. "8-30-10 + Zn" corresponds to NPK fertilizer formulation.

Table 3 Production costs of 1 ha of eucalyptus, corn and fodder (year 1) in the crop-livestock-forest integration system, with a spatial arrangement of $4(3.5 \mathrm{~m} \times 2.5 \mathrm{~m})+36 \mathrm{~m}$, at Boa Vereda's farm in the municipality of Cachoeira Dourada, Goiás, Brazil.

\begin{tabular}{|c|c|c|c|c|c|c|}
\hline \multirow{2}{*}{ Specification } & \multirow{2}{*}{ Unit } & \multicolumn{2}{|c|}{ Quantity } & \multicolumn{2}{|c|}{ Value $(\mathrm{R} \$)^{*}$} & \multirow{2}{*}{ TOC $(\%)$} \\
\hline & & Area $=100 \%$ & Area $=73 \%$ & Unit & Total & \\
\hline \multicolumn{7}{|l|}{ 1. Corn + fodder-year 1} \\
\hline \multicolumn{7}{|l|}{ Inputs } \\
\hline NPK fertilizer (6-23-18 + Zn) & ton & 0.40 & 0.29 & $1,300.00$ & 379.60 & 13.76 \\
\hline FTE fertilizer & $\mathrm{kg}$ & 14.00 & 10.22 & 1.00 & 10.22 & 0.37 \\
\hline NPK coverage fertilizer $(20-0-20)$ & ton & 0.31 & 0.23 & $1,390.00$ & 314.56 & 11.40 \\
\hline Corn seeds & $\mathrm{kg}$ & 18.00 & 13.14 & 22.50 & 295.65 & 10.72 \\
\hline Seed treatment 1 & $\mathrm{~L}$ & 0.10 & 0.07 & 450.00 & 32.85 & 1.19 \\
\hline Herbicide 1 & $\mathrm{~kg}$ & 0.06 & 0.04 & 350.00 & 15.33 & 0.56 \\
\hline Herbicide 2 & $\mathrm{~L}$ & 3.00 & 2.19 & 15.00 & 32.85 & 1.19 \\
\hline Herbicide 3 & $\mathrm{~L}$ & 4.00 & 2.92 & 20.00 & 58.40 & 2.12 \\
\hline Fodder seeds $\mathrm{VC}=76 \%$ & $\mathrm{~kg}$ & 15.00 & 10.95 & 12.00 & 131.40 & 4.76 \\
\hline Post-emergent herbicide 1 & $\mathrm{~L}$ & 3.00 & 2.19 & 15.00 & 32.85 & 1.19 \\
\hline Formicidal bait & $\mathrm{kg}$ & 0.50 & 0.37 & 9.00 & 3.29 & 0.12 \\
\hline Acaricide insecticide & $\mathrm{L}$ & 0.80 & 0.58 & 23.00 & 13.43 & 0.49 \\
\hline Insecticide & $\mathrm{kg}$ & 1.00 & 0.73 & 48.00 & 35.04 & 1.27 \\
\hline Physiological insecticide & $\mathrm{L}$ & 0.70 & 0.51 & 53.00 & 27.08 & 0.98 \\
\hline Fungicide 1 & $\mathrm{~kg}$ & 1.50 & 1.10 & 26.00 & 28.47 & 1.03 \\
\hline Fungicide 2 & $\mathrm{~L}$ & 0.50 & 0.37 & 67.00 & 24.46 & 0.89 \\
\hline Subtotal of inputs & & & & & $1,435.47$ & 52.04 \\
\hline
\end{tabular}


(Table 3 continued)

\begin{tabular}{|c|c|c|c|c|c|c|}
\hline \multirow{2}{*}{ Specification } & \multirow{2}{*}{ Unit } & \multicolumn{2}{|c|}{ Quantity } & \multicolumn{2}{|c|}{ Value $(\mathrm{R} \$)^{*}$} & \multirow{2}{*}{$-\mathrm{TOC}(\%)$} \\
\hline & & Area $=100 \%$ & Area $=73 \%$ & Unit & Total & \\
\hline \multicolumn{7}{|l|}{ Services } \\
\hline Application of desiccant & ha & 1.00 & 0.73 & 10.00 & 7.30 & 0.26 \\
\hline Application of formicide & ha & 1.00 & 0.73 & 8.00 & 5.84 & 0.21 \\
\hline $\begin{array}{l}\text { Planting and application of fertilizer for } \\
\text { corn and fodder }\end{array}$ & ha & 1.00 & 0.73 & 50.00 & 36.50 & 1.32 \\
\hline Application of hedge fertilizer & ha & 1.00 & 0.73 & 25.00 & 18.25 & 0.66 \\
\hline Application of post-emergent herbicide & ha & 1.00 & 0.73 & 10.00 & 7.30 & 0.26 \\
\hline Application of physiological insecticide & ha & 1.00 & 0.73 & 18.00 & 13.14 & 0.48 \\
\hline Internal transportation & ha & 1.00 & 0.73 & 10.00 & 7.30 & 0.26 \\
\hline Harvest and freight & ha & 1.00 & 0.73 & 180.00 & 131.50 & 4.77 \\
\hline Subtotal of services & & & & & 227.03 & 8.23 \\
\hline TOC for corn and fodder & & & & & $1,662.50$ & 60.27 \\
\hline \multicolumn{7}{|l|}{ 2. Eucalyptus-year $1($ deployment area $=27 \%)$} \\
\hline \multicolumn{7}{|l|}{ Inputs } \\
\hline NPK fertilizer $(20-0-20+2 \% B+Z n)$ & $\mathrm{kg}$ & - & 34.40 & 1.20 & 41.28 & 1.50 \\
\hline Boric acid fertilizer $-15 \mathrm{~g} / \mathrm{plant}$ & $\mathrm{kg}$ & - & 5.16 & 3.20 & 16.51 & 0.60 \\
\hline Formicide & $\mathrm{kg}$ & 10.00 & - & 9.00 & 90.00 & 3.26 \\
\hline Herbicide & $\mathrm{L}$ & 0.80 & 0.22 & 20.00 & 4.32 & 0.16 \\
\hline Subtotal of inputs & & & & & 152.11 & 5.51 \\
\hline \multicolumn{7}{|l|}{ Services } \\
\hline Application of fertilizers & daily & - & 0.34 & 80.00 & 27.52 & 1.00 \\
\hline Manual spraying of pre-emergent herbicide & daily & 0.75 & 0.20 & 80.00 & 16.20 & 0.59 \\
\hline Application of formicide & daily & 0.25 & - & 80.00 & 20.00 & 0.73 \\
\hline Pruning the trees ${ }^{* *}$ & daily & - & 2.00 & 80.00 & 160.00 & 5.80 \\
\hline Subtotal of services & & & & & 223.72 & 8.11 \\
\hline Operational costs of eucalyptus & & & & & 375.83 & 13.63 \\
\hline \multicolumn{7}{|l|}{ 3. Other costs-year 1} \\
\hline Opportunity cost of land (rent) & sack & 10.00 & - & 72.00 & 720.00 & 26.10 \\
\hline TOC-year 1 & & & & & $2,758.33$ & 100.00 \\
\hline
\end{tabular}

${ }^{*}$ October 15th, 2017; US\$1.00 = R\$3.146.

TOC: total operational cost; VC: cultural value (index used to know the quality of the seeds).

"6-23-18 + Zn", "20-0-20" and "20-0-20 + 2\% B + Zn" correspond to NPK fertilizers formulations.

** The pruning of the trees consists of the artificial cut of the branches that are placed along the shaft to improve the quality of the wood.

Table 4 Production costs of 1 ha of eucalyptus, fodder and livestock (year 2) in the crop-livestock-forest integration system, with a spatial arrangement of $4(3.5 \mathrm{~m} \times 2.5 \mathrm{~m})+36 \mathrm{~m}$, at Boa Vereda's farm in the municipality of Cachoeira Dourada, Goiás, Brazil.

\begin{tabular}{|c|c|c|c|c|c|c|}
\hline \multirow[b]{2}{*}{ Specification } & \multirow[b]{2}{*}{ Unit } & \multicolumn{2}{|c|}{ Quantity } & \multicolumn{2}{|c|}{ Value $(\mathrm{R} \$)^{*}$} & \multirow[b]{2}{*}{ TOC $(\%)$} \\
\hline & & $\begin{array}{l}\text { Area }=100 \% \\
(\text { fodder }+ \text { cattle) }\end{array}$ & $\begin{array}{l}\text { Area }=27 \% \\
\text { (eucalyptus) }\end{array}$ & Unit & Total & \\
\hline \multicolumn{7}{|l|}{ 1. Beef cattle + fodder-year 2} \\
\hline \multicolumn{7}{|l|}{ Inputs } \\
\hline Acquisition of cattle & head & 3.00 & - & $1,153.53$ & $3,460.60$ & 59.38 \\
\hline $\begin{array}{l}\text { Vaccines }+ \text { manual labour }+ \\
\text { medicines }-12 \times\end{array}$ & head & 3.00 & - & 48.00 & 144.00 & 2.47 \\
\hline Supplementation/dry season $-6 \times$ & head & 3.00 & - & 50.85 & 152.55 & 2.62 \\
\hline Supplementation/wet season $-6 \times$ & head & 3.00 & - & 69.30 & 207.90 & 3.57 \\
\hline Fodder maintenance (rental value) $-12 \times$ & head & 3.00 & - & 240.00 & 720.00 & 12.35 \\
\hline Capital investment fees $-6.75 \%$ year & head & 3.00 & - & 77.86 & 233.59 & 4.01 \\
\hline \multicolumn{2}{|l|}{ Total costs for beef cattle and fodder-year 2} & & & & $4,918.64$ & 84.39 \\
\hline
\end{tabular}


(Table 4 continued)

\begin{tabular}{|c|c|c|c|c|c|c|}
\hline \multirow[b]{2}{*}{ Specification } & \multirow[b]{2}{*}{ Unit } & \multicolumn{2}{|c|}{ Quantity } & \multicolumn{2}{|c|}{ Value $(\mathrm{R} \$)^{*}$} & \multirow[b]{2}{*}{ TOC $(\%)$} \\
\hline & & $\begin{array}{l}\text { Area }=100 \% \\
(\text { fodder }+ \text { cattle) }\end{array}$ & $\begin{array}{l}\text { Area }=27 \% \\
\text { (eucalyptus) }\end{array}$ & Unit & Total & \\
\hline \multicolumn{7}{|c|}{ 2. Eucalyptus-year $2($ deployment area $=27 \%)$} \\
\hline \multicolumn{7}{|l|}{ Inputs } \\
\hline Fertilizer (boric acid) & $\mathrm{kg}$ & - & 6.88 & 3.20 & 22.02 & 0.38 \\
\hline Pruning the trees ${ }^{* *}$ & $\mathrm{~kg}$ & 10.00 & - & 1.00 & 10.00 & 0.17 \\
\hline Subtotal of inputs & & & & & 32.02 & 0.55 \\
\hline \multicolumn{7}{|l|}{ Services } \\
\hline Application of formicide & daily & 0.25 & - & 80.00 & 20.00 & 0.34 \\
\hline Application of fertilizer (boric acid) & daily & - & 0.34 & 80.00 & 27.52 & 0.47 \\
\hline Pruning the trees ${ }^{* *}$ & daily & - & 1.38 & 80.00 & 110.08 & 1.89 \\
\hline Subtotal of services & & & & & 157.60 & 2.70 \\
\hline Total costs of eucalyptus-year 2 & & & & & 189.62 & 3.25 \\
\hline \multicolumn{7}{|l|}{ 3. Other costs-year 2} \\
\hline Opportunity cost of land (rent) & sack & 10.00 & - & 72.00 & 720.00 & 12.35 \\
\hline TOC-year 2 & & & & & $5,828.26$ & 100.00 \\
\hline
\end{tabular}

${ }^{*}$ October 15th, 2017; US\$1.00 = R\$3.146.

** The pruning of the trees consists of the artificial cut of the branches that are placed along the shaft to improve the quality of the wood.

TOC: total operational cost.

In this evaluation, the concept of total operational cost (TOC) was considered as the sum of direct expenses effectively disbursed by the producer, plus the depreciation of machinery and specific improvements of the activity, labor value and taxes and associated taxes production [24]. A rate of $6.75 \%$ per year was used as the opportunity cost of capital invested in the acquisition of animals.

The opportunity costs attributed to the productive activity were also taken into consideration for the remuneration of fixed capital on land. The opportunity cost of the land was established in 10 sacks of soybeans per hectare, with each sack of soybean equal to $60 \mathrm{~kg}$. This value was defined as an easy-access option for producers in the region. In order to maintain pasture support capacity, it is necessary to carry out periodic maintenance and rotation fertilization, the cost considered for this practice was based on the amount paid for the pasture rental in the region of $\mathrm{R} \$ 20.00$ animal/month.

The purchase price of the steers was established based on the value of the beef arroba, plus $10 \%$, since the market usually pays more value for it. In addition to maintenance of the pasture and purchase of a supplement, it is also included in the cost composition, the amount of $\mathrm{R} \$ 4.00$ animal $/$ month, related to vaccines, labor and medication expenses.

The operational cost for implementing each eucalyptus seedling was $\mathrm{R} \$ 2.21$, which is an average value observed in the region. The cost of maintaining the eucalyptus seedlings during the two years following their planting is basically composed of fertilizers and formicides, and the latter was applied regularly until the end of the project.

In the 2009/2010 harvest, the average yield of soybeans in the system was $2,520.00 \mathrm{~kg} / \mathrm{ha}$, and this productivity accounted for $73 \%$ of the area of each hectare. For comparison purposes, this productivity would correspond to $3,452.05 \mathrm{~kg} / \mathrm{ha}$ in $100 \%$ of the area. In the same harvest, the average yield of soybeans under traditional monoculture conditions was $2,927.00 \mathrm{~kg} / \mathrm{ha}$ in Brazil, 2,997.00 kg/ha in the central-west region and $2,880.00 \mathrm{~kg} / \mathrm{ha}$ in the state of Goiás [25].

In the 2010/2011 harvest, the average yield of corn in the system was $5,280.00 \mathrm{~kg} / \mathrm{ha}$, and this 
productivity accounted for $73 \%$ of the area of 1 ha. In the same harvest, the average corn yield under traditional monoculture conditions was $4,481.00$ $\mathrm{kg} / \mathrm{ha}$ in Brazil, 7,547.00 kg/ha in the central-west region and $7,850.00 \mathrm{~kg} / \mathrm{ha}$ in the state of Goiás [25]. It is observed that the average yield of corn obtained in the system was higher than the Brazilian national average and, at the same time, it was compatible with the implantation of the fodder and animal components.

The estimated productivity of beef cattle was 18 arrobas/ha/year, and this productivity was, on average, three times higher than that previously obtained in that area. In the dry season, the animals consumed an average of $0.25 \mathrm{~kg}$ of supplement per day in the system, resulting in an average daily gain of $0.40 \mathrm{~kg}$. In rainy periods, because the animals were already heavier, they started consuming more supplement, on average $0.35 \mathrm{~kg} /$ animal and the average gain observed was $0.70 \mathrm{~kg} / \mathrm{d}$. Each animal was sold with an average weight of $400 \mathrm{~kg}$.

The average wood productivity estimate was 37.50 $\mathrm{m}^{3} /$ ha/year in the integration system. It should be noted that this estimate is identical to the average productivity of eucalyptus in Brazilian territory, but under monoculture conditions [26]. This means that a crop-livestock-forest integration system with only 344 trees/ha is capable of reaching levels of volumetric productivity of wood, similar to a traditional eucalyptus monoculture in Brazil, whose average varies between 1,111 trees (planted in spacing of 3.0 $\mathrm{m} \times 3.0 \mathrm{~m}$ ) and 1,667 trees (planted in spacing of 3.0 $\mathrm{m} \times 2.0 \mathrm{~m}$ ) per hectare. Furthermore, the existence of fewer trees that consequently resulted in less competition among them for resources, such as water, light and soil nutrients should also be considered as a factor contributing to increased productivity. The trees are also indirectly benefited annually by the application of fertilizers in the agricultural components (soybean and corn) and also in the fodder. This aspect proves the efficiency of crop-livestock-forest integration systems in the use of available resources. From the above, the enormous potential of crop-livestock-forest integration systems in raising agricultural productivity in rural properties can be seen.

In general, the crop-livestock-forest integration systems presented a cash flow with regular revenues throughout the period under consideration, with more significant results from the sale of wood harvested for fuelwood at the age of six and sawmill usage at age 14 (Table 5). In year 0 and year 1 , the proceeds from the commercialization of the grains are necessary to cover part of the amount spent on the planting and maintenance of trees. Annual crops, in addition to providing a faster financial return, provide other benefits, such as fertilization and cultural dealings that indirectly favor the growth of eucalyptus. Starting with the second year, in addition to the annual maintenance costs of the eucalyptus, the costs associated with the buying and selling of meat cattle also occurred.

The analysis of the economic viability is fundamental for the decision making regarding the implantation and conduction of the system, considering the different economic activities that compose it. Estimates of NPV and EAUV obtained in scenario 1 , which considers a total cut of the trees at the age of six years, with commercialization of fuelwood, were lower than scenario 2, which considers the $30 \%$ of the trees at six years of age for fuelwood and final cut of the remnants at the age of 14 , for the use of lumber in sawmills. The high values obtained in relation to scenario 2 can be explained by the value added to the wood that has occurred over the years. At the age of 14, the remaining trees in the system are characterized by being vigorous, with better shape and quality of the bole, higher wood volume and higher heartwood ratio in relation to the sapwood and consequently have a market value higher than those for fuelwood harvested at six years of age.

It is also worth remembering that in the present work 
Table 5 Production costs of 1 ha (considering two scenarios) of the crop-livestock-forest integration system, at Boa Vereda's farm, Cachoeira Dourada municipality, Goiás, Brazil.

\begin{tabular}{|c|c|c|c|c|c|}
\hline \multicolumn{6}{|c|}{ Scenario 1: fuelwood (six years) } \\
\hline Year & Costs $(\mathrm{R} \$)^{*}$ & Gross income $(\mathrm{R} \$)^{*}$ & Net margin $(\mathrm{R} \$)^{*}$ & $\mathrm{NPV}(\mathrm{R} \$)^{*}$ & EAUV $(\mathrm{R} \$)^{*}$ \\
\hline$\overline{0}$ & $3,136.98$ & $3,048.48$ & -88.50 & & \\
\hline 1 & $2,758.33$ & $1,839.60$ & -918.73 & & \\
\hline 2 & $5,828.26$ & $6,034.60$ & 206.34 & & \\
\hline 3 & $5,749.82$ & $6,034.60$ & 284.78 & & \\
\hline 4 & $5,658.64$ & $6,034.60$ & 375.96 & & \\
\hline 5 & $5,658.64$ & $6,034.60$ & 375.96 & & \\
\hline 6 & $5,799.68$ & $18,409.60$ & $12,609.92$ & $8,548.04$ & $1,779.52$ \\
\hline \multicolumn{6}{|c|}{ Scenario 2: roughing fuelwood (six years) and final cut wood for sawmills (14 years) } \\
\hline 0 & $3,136.98$ & $3,048.48$ & -88.50 & & \\
\hline 1 & $2,758.33$ & $1,839.60$ & -918.73 & & \\
\hline 2 & $5,828.26$ & $6,034.60$ & 206.34 & & \\
\hline 3 & $5,749.82$ & $6,034.60$ & 284.78 & & \\
\hline 4 & $5,658.64$ & $6,034.60$ & 375.96 & & \\
\hline 5 & $5,658.64$ & $6,034.60$ & 375.96 & & \\
\hline 6 & $5,658.64$ & $9,747.10$ & $4,088.46$ & & \\
\hline 7 & $5,658.64$ & $6,034.60$ & 375.96 & & \\
\hline 8 & $5,658.64$ & $6,034.60$ & 375.96 & & \\
\hline 9 & $5,658.64$ & $6,034.60$ & 375.96 & & \\
\hline 10 & $5,658.64$ & $6,034.60$ & 375.96 & & \\
\hline 11 & $5,658.64$ & $6,034.60$ & 375.96 & & \\
\hline 12 & $5,658.64$ & $6,034.60$ & 375.96 & & \\
\hline 13 & $5,658.64$ & $6,034.60$ & 375.96 & & \\
\hline 14 & $5,799.68$ & $93,109.60$ & $87,309.92$ & $39,158.31$ & $4,410.66$ \\
\hline
\end{tabular}

* October 15th, 2017; US\$1.00= R\$3.146.

the selling price of standing timber was considered, i.e., it is the responsibility of the buyer of the wood to bear the costs of cutting, shipping and transporting the wood. If the rural producer could be further motivated in order to add more value to his product, he could acquire a mobile sawmill and carry out primary (rough cut) and secondary (cutting boards) wood processing. In this case, the marketing value of the wood could jump from $\mathrm{R} \$ 180.00$ of standing timber up to $R \$ 1,800.00$ for the sale of cut lumber to the consumer.

Considering the results of NPV and EAUV indicators, the crop-livestock-forest integration system is economically competitive with the profitability of various options offered in the financial market. However, scenario 2 was significantly higher than scenario 1 under the economic aspect. There is a clear reduction in risks due to improvements in production conditions and the diversification of commercial activities, since this greater diversification tends to reduce annual net income variations, increasing the efficiency of the factors of production.

\section{Conclusions}

The crop-livestock-forest integration system represents an economically viable alternative that, among other environmental and social benefits, allows the diversification of its sources of income, with a reduction of risk.

\section{Acknowledgments}

The authors would like to thank Embrapa, the Rede de Fomento ILPF and Universidade Federal de Goiás for facilitating this research. 


\section{References}

[1] Balbino, L. C., Cordeiro, L. A. M., Porfírio-da-Silva, V., Moraes, A., Martinez, G. B., Alvarenga, R. C., Kichel, A. N., Fontaneli, R. S., Dos Santos, H. P., Franchini, J. C., and Galerani, P. R. 2011. "Technological Evolution and Productive Arrangements of Crop-Livestock-Forest Integration Systems in Brazil.” Pesquisa Agropecuária Brasileira 46 (10): 1301-9. (in Portuguese)

[2] Macedo, R. L. G., Vale, A. B., and Venturin, N. 2010. Eucalyptus in Agroforestry Systems. Lavras: UFLA, 331.

[3] Balbino, L. C., Cordeiro, L. A. M., Oliveira, P., Kluthcouski, J., Galerani, P. R., and Vilela, L. 2012. "Sustainable Agriculture through Crop-Livestock-Forest Integration.” Informações Agronômicas 138 (18). (in Portuguese)

[4] Combe, J., and Budowski, G. 1979. "Classification of Agroforestry Techniques: A Literature Review." In Proceeding of Agroforestry Systems Workshop in Latin America. Turrialba: Actas, 7-48. (in Spanish)

[5] Cordeiro, L. A. M., Vilela, L., Marchão, R. L., Kluthcouski, J., and Martha Júnior, G. B. 2015. "Integration of Crop-Livestock and Crop-Livestock-Forest Integration: Strategies for Sustainable Intensification." Cadernos de Ciência e Tecnologia 32 (1/2): 5-43. (in Portuguese)

[6] Montagnini, F. 1992. Agroforestry Systems: Principles and Applications in the Tropics. San Jose: Organization for Tropical Studies, 622.

[7] Embrapa. 2016. "Crop-Livestock-Forest Integration in Numbers." Accessed September 27, 2017. https://www.embrapa.br/busca-de-publicacoes/-/publicac ao/1064859/ilpf-em-numeros. (in Portuguese)

[8] Venturin, R. P., Guerra, A. R., Macedo, R. L. G., Venturin, N., and Mesquita, H. A. 2010. "Agrosilvipastoral Systems: Origin, Modalities and Models of Implantation." Informe Agropecuário 31: 16-24.

[9] Pacheco, A. R., Nicoli, C. M. L., Calil, F. N., Reis, C. F., and Da Cunha Moraes, A. 2016. A Decade of Technological Innovation in Crop-Livestock-Forest Integration in Fazenda Boa Vereda. Colombo: Embrapa Florestas, 392.

[10] Pacheco, A. R., Chaves, R. Q., and Nicoli, C. M. L. 2013. "Integration of Crops-Livestock-Forestry: A System of Production for the Brazilian Cerrado." In Eco-efficiency: From Vision to Reality, edited by Hershey, C. H., and Neate, P. Colombia: Centro Internacional de Agricultura Tropical, 51-62.

[11] Assis, P. C. R., Stone, L. F., Medeiros, J. C., Madari, B. E., Oliveira, J. De M., and Wruck, F. J. 2015. "Soil Physical Attributes in Crop-Livestock-Forest Integration Systems.” Revista Brasileira de Engenharia Agrícola e Ambiental 19 (4): 309-16. (in Portuguese)
[12] Coelho Júnior, J. M. L. P., Silva Neto, C. M. E., Souza, K. R., Guimarães, L. E., Oliveira, F. D., Goncalves, R. A., Monteiro, M. M., Lima, N. L., Venturoli, F., and Calil, F. N. 2016. "Volumetric Models for Eucalyptus urograndis in a Crop-Livestock-Forest Integration (CLFI) System in the Brazilian Cerrado." African Journal of Agricultural Research 11: 1336-43.

[13] Ferreira, E. M., Santana, A. V., Calil, F. N., Tsai, H. M., and Costa, L. F. S. 2014. "Resistance to Soil Penetration under a Crop-Livestock-Forest Integration System, Conventional Pasture and Cerrado Native Forest." Enciclopédia Biosfera 10: 2675-80. (in Portuguese)

[14] Hungria, M., Nogueira, M. A., and Araujo, R. S. 2015. "Alternative Methods of Soybean Inoculation to Overcome Adverse Conditions at Sowing." African Journal of Agricultural Research 10 (23): 2329-38.

[15] Hungria, M., Nogueira, M. A., and Araujo, R. S. 2015. "Soybean Seed Co-inoculation with Bradyrhizobium spp. and Azospirillum brasilense: A New Biotechnological Tool to Improve Yield and Sustainability." American Journal of Plant Sciences 6: 811-7.

[16] Kaschuk, M. A. N., De Luca, M. J., and Hungria, M. 2016. "Response of Determinate and Indeterminate Soybean Cultivars to Basal and Topdressing N Fertilization Compared to Sole Inoculation with Bradyrhizobium." Field Crops Research 195: 21-7.

[17] Fukami, J., Nogueira, M. A., Araujo, R. S., and Hungria, M. 2016. "Accessing Inoculation Methods of Maize and Wheat with Azospirillum brasilense." AMB Express 6 (3): $1-13$.

[18] Lisboa, F. J. G., Chaer, G. M., Fernandes, M. F., Berbara, R. L. L., and Madari, B. E. 2014. "The Match between Microbial Community Structure and Soil Properties Is Modulated by Land Use Types and Sample Origin within an Integrated Agroecosystem." Soil Biology \& Biochemistry 78: 97-108.

[19] Marks, B. B., Megías, M., Ollero, F. J., Nogueira, M. A., Araujo, R. S., and Hungria, M. 2015. "Maize Growth Promotion by Inoculation with Azospirillum brasilense and Metabolites of Rhizobium tropici Enriched on Lipo-Chitooligosaccharides (LCOs)." AMB Express 71 (5): 2-11.

[20] Wruck, F. J., Behling, M., and Antonio, D. B. A. 2015. "Integrated Systems in Mato Grosso and Goiás." In Agroforestry Systems: Sustainable Agriculture, edited by Laura, W. A., Alves, F. V., and Almeida, R. G. Brasília: Embrapa, 169-94.

[21] Buarque, C. 1984. Economic Evaluation of Projects. Rio de Janeiro: Elsevier. (in Portuguese)

[22] Rezende, J. L. P., and Oliveira, A. D. 2001. Economic and Social Analysis of Forestry Projects. Viçosa: Universidade Federal de Viçosa, 389. 
[23] Martin, N. B., Serra, R., Oliveira, M. D. M., Ângelo, J. A., and Okawa, H. 1998. "Integrated System of Agricultural and Livestock Costs.” Informações Econômicas 28 (1): 7-28.

[24] Matsunaga, M., Bemelmans, P. F., De Toledo, P. E. N., Dulley, R. D., Okawa, H., and Pedroso, I. A. 1976. "Cost Methodology Used by the Institute of Agricultural Economics." Agricultura em São Paulo 23: 123-39.

[25] Brazil. 2017. Ministry of Agriculture Livestock and
Supply. National Supply Company. "Historical Series of Crops." Accessed September 27, 2017. http://www.conab. gov.br/conteudos.php?a=1252\&Pagina_objemsconteudos =3\#A_objcmsconteudos. (in Portuguese)

[26] Brazilian Tree Industry (BTI). 2017. Indicators of Performance of the National Sector of Planted Trees for the Year 2016. Report BTI 2017. Accessed September 27, 2017. http://iba.org/images/shared/Biblioteca/IBA RelatorioAnual2017.pdf. (in Portuguese) 